\title{
The Role of Women in Lok Baintan Floating Market, South Kalimantan: Implication for Tourism Development
}

\author{
Deasy Arisanty ${ }^{1 *}$, Ellyn Normelani ${ }^{1}$, Herry Porda Nugroho Putro ${ }^{2}$, Moh. Zaenal Arifin Anis ${ }^{3}$ \\ ${ }^{1}$ Department of Geography Education, Faculty of Teacher Training and Education, Lambung Mangkurat University, \\ Banjarmasin, Indonesia \\ ${ }^{2}$ Master of Social Science Education, Faculty of Teacher Training and Education, Lambung Mangkurat University, \\ Banjarmasin, Indonesia \\ ${ }^{3}$ Department of History Education, Faculty of Teacher Training and Education, Lambung Mangkurat University, \\ Banjarmasin, Indonesia
}

\begin{abstract}
Lok Baintan Floating Market is the tourism destination in South Kalimantan. Trading activity in Lok Baintan become the tourism attraction, which traders in the Floating Market are women using the small boat (jukung). The objective of research is to analyze the role of women in Lok Baintan Floating Market. The study uses fieldwork and qualitative approach. Research data is obtained through interviews with traders in the Floating Market. The research shows that women have the important role in floating market. The role of women is to prepare the merchandise the day before selling until then they sell in the floating market in next day. Merchandise is sold by women in the floating market such as agricultural products, fishery products, handicrafts, traditional cuisine, and traditional cakes. Women get both agricultural product and fishery product from their own land or from other traders. Women make their own craft and then sold in the floating market. Women make both traditional dishes and traditional cake and then sold in the floating market. The presence of women in Lok Baintan has improved the local socio-economics of community. In the perspective of tourism development in floating market, there is still need women community empowerment.
\end{abstract}

Keywords: floating market, tourism destination, women role.

\section{INTRODUCTION}

Lok Baintan Floating Market is one of tourism destination in South Kalimantan. The trading activity using small boat or jukung becomes the attractiveness in Lok Baintan Floating Market [13]. Lok Baintan floating market related to the human culture in South Kalimantan as the river culture. Many people in South Kalimantan live along the river. River forms the culture of community in South Kalimantan [3].

One of the attractiveness in Lok Baintan is the domination of women traders. Women have ability to paddle her jukung while offering their wares. The women activity becomes tourism attractiveness in Lok Baintan Floating Market [1]. Women sell their merchandise from sunrise to about 8 am [4].

Floating markets have provided jobs for women. Women trade the local product which is harvested from gardens in Lok Baintan Floating Market. The activity of women in Lok Baintan Floating Market is important to increase income

\footnotetext{
${ }^{*}$ Correspondence address:

Deasy Arisanty

Email : deasyarisanty@unlam.ac.id

Address : Brigjen H. Hasan Basry, Banjarmasin, South Kalimantan, Indonesia
}

for their family through trading activity. Lok Baintan Floating Market is also decreased the unemployed in this villages. The women use their income for their children and household necessities [5].

Women have important roles for socioeconomics increase in the community. Women can become a development agent due to the important role in both formal and informal economic sector through creativity and innovation [5]. Women in Lok Baintan Floating Market work in the informal sector. Women in Lok Baintan work only half the time in the morning, hence they has the time for their family. Women have the opportunity to work in informal sector than man [6].

Women have the important roles for tourism development. Tourism gives the opportunity to empower women by economic empowerment, educational empowerment, and political empowerment [7]. Tourism provides the benefits for local community, including women. In the context of community development, tourism is a crucial role for local development. It is especially important in developing countries with abundance natural and cultural resources [8]. The condition of women in tourism are still underpaid, under-utilized, under-educated, and 
underrepresented; but tourism gets the opportunity to success [9]. The condition of tourism in Lok Baintan that determines the success of tourism activity in Lok Baintan depends on the women. Based on the background, the objective of research is to analyze the role of women in Lok Baintan Floating Market for tourism development implication.

\section{RESEARCH METHOD}

\section{Study Area and Data Collection}

Floating market is located in $3^{\circ} 17^{\prime} 21.1^{\prime \prime} \mathrm{S}$ and $114^{\circ} 40^{\prime} 11.1^{\prime \prime}$ E. Lok Baintan Floating Market location is in Banjar Regency, South Kalimantan [10]. Lok Baintan location is presented in Figure 1. The study used fieldwork and qualitative approach. The target population were woman traders in Lok Baintan Floating Market, consist of handicraft traders, agricultural product traders, fish traders, and culinary traders [10]. Data collection was obtained through observation and depth interview. Observation was used to get the general condition about the women activity in Lok Baintan Floating Market. Depth interview was used to get the information about role of women during the trading activity in Lok Baintan Floating Market. Triangulation was used to test the validity of data [11].

\section{Data Analysis}

Data analysis consisted of data grouping, data reduction, data display, and conclusion drawing
[11]. Grouping of data was based on the type of commodities sold in the floating market. Data reduction was used to get the tentative conclusion based on the similarities and differences of women role in Lok Baintan Floating Market. Data display present data of women activity in Lok Baintan in form of matrix. Data display was used to make it easier to determine advanced conclusions. Conclusion drawing was used to get the final conclusion and to get the relation between categories.

\section{RESULT AND DISCUSSION}

Women prepare merchandise before it is sold on a floating market. Women prepare their merchandise one day before market day. Merchandise consists of handicraft, agriculture product, fishery product, culinary product.

\section{Handicraft product}

Women get their merchandise from other craftsmen or from their own craft. A total of 10 merchants sell handicrafts from other craftsmen. The role of the merchant is to collect handicrafts from craftsmen for resale in the floating market. Women also sell their own handicraft. The role of women is as the craftsmen and traders. The craft is made traditionally and hereditary. The handicraft from Lok Baintan consists of purun hats and basket. The material used is derived from purun plant and palm tree. Lack of capital and production costs causes the limited of handicraft.

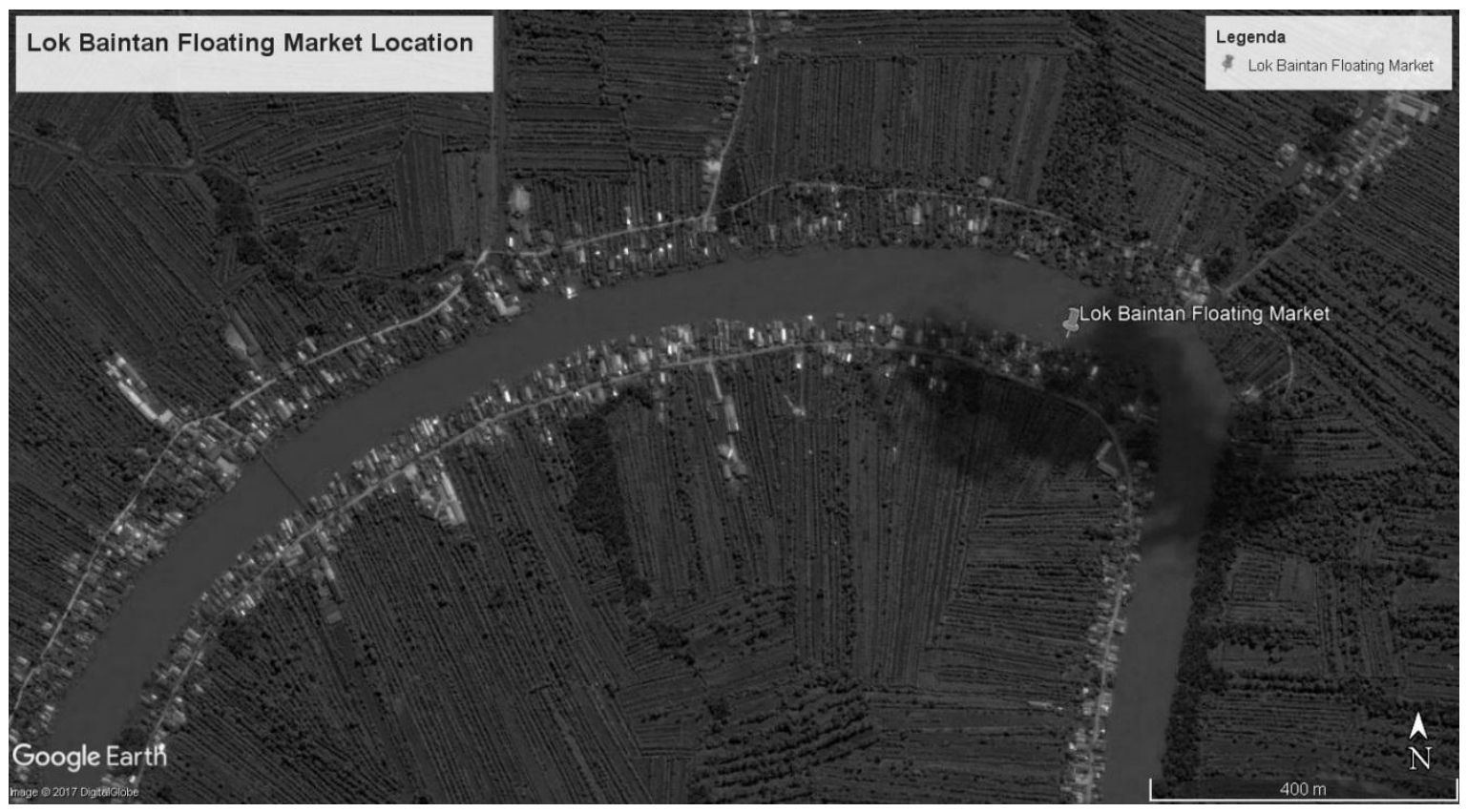

Figure 1. Lok Baintan Floating Market Location. Source: Google Earth 


\section{Agriculture Product}

Agriculture products in Lok Baintan Floating Market consist of oranges, grapefruit, pineapple, banana and vegetables. Traders gets the agricultural product from the others farmers and their own farm. Many crops often planted and cultivated in traditional home garden. In tropical countries, the home gardens often play an important role in households economic earning [12].

Women collect agriculture product from agricultural land around the floating market. They also collect from other traders in other traditional markets. The agricultural products are resold in the floating market. The role of women in this process is to collect agricultural products to resale in the Floating Market in next morning. They get income from the price difference between the price at the merchant or at other farmers and the price in the floating market.

Women in the Floating Market also act as traders and farmers. They get the crops from their own farmland (Fig. 2) in the afternoon and then resold them in the floating market the next morning (Fig. 3). The main farm is managed by men. Women help their husbands to manage farmland. The woman's job is to harvest the crops for later selling at the floating market.

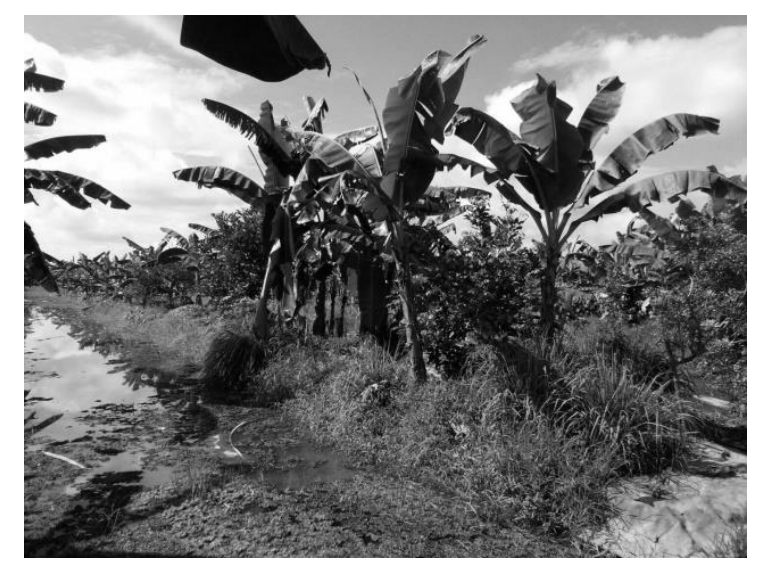

Figure 2. The Farmland in Lok Baintan Village

\section{Fishery Product}

Women in the Floating Market get fish in ponds or in rivers around Lok Baintan Village. They also get fish from other merchants such as salted sepat fish.

The role of women is to collect fish from ponds (Fig. 4), rivers or other fish traders. Men have the role for ponds managing or fish catching in rivers. Women have a role to help men to sell the fish in the floating market. Usually fish are collected the day before they sell in the floating market.

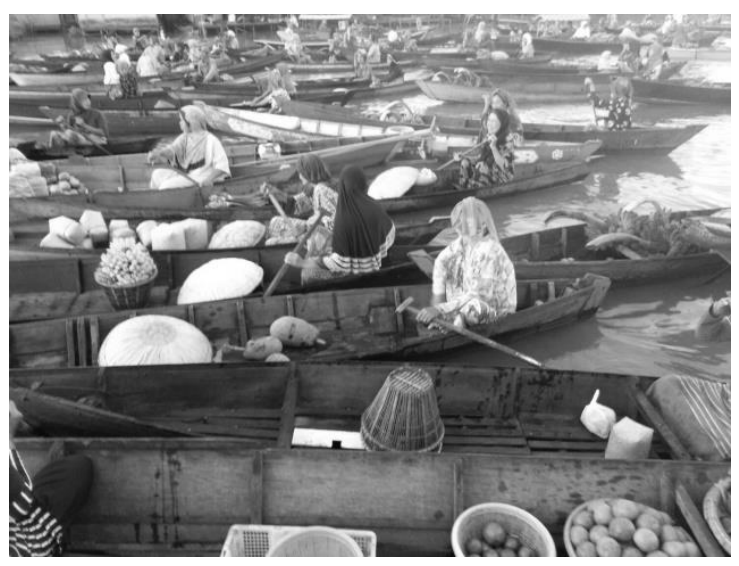

Figure 3. Women Trades Agriculture Product Using jukung

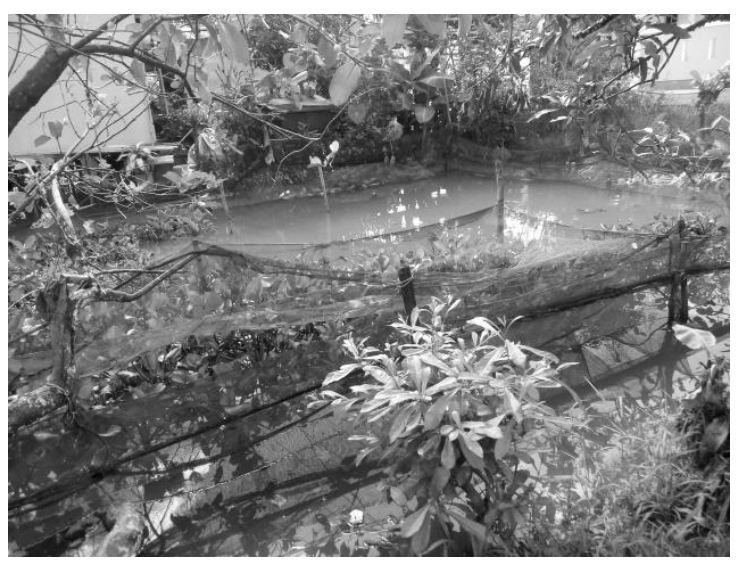

Figure 4. Fish Pond in Lok Baintan Village

\section{Traditional Cuisine}

Women sell traditional cakes and traditional food by jukung (Fig. 5). Cuisine are made by traders or bought from traders in other traditional markets. Women have the role as the traders and food maker.

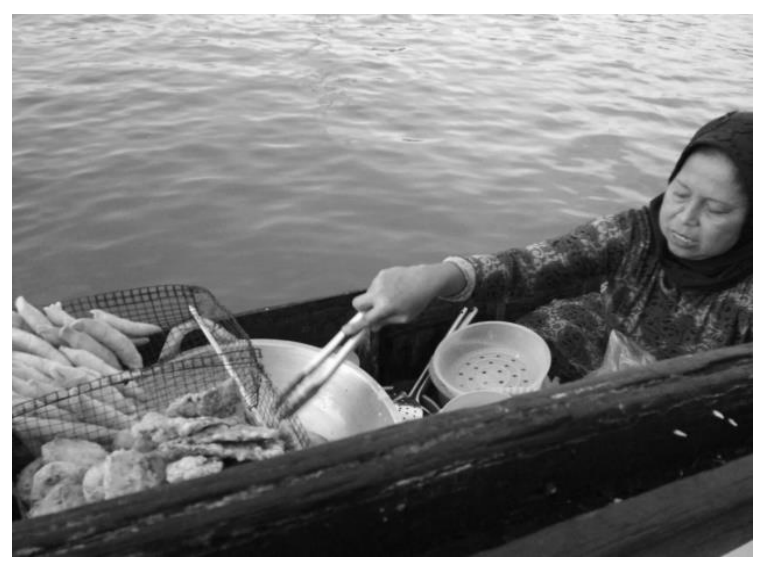

Figure 5. Traditional Cakes on Lok Baintan Floating Market 
Women have a very important role for trading activities in the floating market. Their role is from preparing merchandise until to sell in a floating market. Women existence has been the driving force for local economy in this village. Women have increased the tourism activity in Lok Baintan Floating Market.

In the recent rapid development of culinary tourism, the local cuisine should be able promotes and attract tourist. In such a case, an intensive study about resources and local culture to enhance the value of local cuisine is important. Traditional social and culture have the relation to the traditional cuisine [13]. The cuisine The Banjarese traditional cuisine need to be explored and studied for future culinary tourism development.

Lok Baintan Floating Market is a place for community gathering. They can meet and discuss about their daily lives. Women can exchange information, such as birth of a child or grandchild, marriage, social gathering, merchant information, and others. Socially, the floating market can improve the social life quality of community. Women gets the social benefit from tourism entrepreneurship that have the implication for tourism development [14].

The cultural and belief has an impact for women participation in labor force participation [15]. Women and men in Lok Baintan Floating Market have divided their roles in economic and social life. Men work on farmland, which the agricultural produce is sold by women in the floating market. When women sell in a floating market, their husbands are willing to help for finishing the house chores. Tourism sector has provided opportunities for both women and men to get better jobs [16].

The division of labor between women and men will result in social change, economic growth and gender equality. It is very important for local economy development. The limitations of women's participation are due to tradition, economic losses, and low education [17]. Equality of gender can increase the economic growth, but economic growth doesn't have impact for gender equality [18].

Women choose the part time work rather than full time work, and informal sector rather than formal sector [18]. Percentage of working women in tourism is high, but they gets the low income [19]. Women have lower incomes than men; even though they work in the same position [16].
Women in lok Baintan floating Market works in part time and informal sector. They work in the morning as the traders, and then they collect the merchandise in the afternoon. The condition causes the low income of women in Lok Baintan Floating Market.

\section{The Implication for Tourism Development}

Women roles in tourism sector are determined by demands of tourist. Women have proved as are agents for building capacities of tourism sector [17]; but demand of tourism determines the woman empowerment [18], [20], [21]. Tourism industry has the high contribute for women empowerment [22].

Women become very important in the presence of the tourism in Lok Baintan floating market. Women role during preparing the merchandise until trading in next morning become the tourism attraction in Lok Baintan Floating Market. Tourist wants to see the women activity in Lok Baintan Floating Market. Tourist also wants to buy the merchandise. Tourist visits determine the income for women in Lok Baintan Floating Market.

Women empowerment in this floating market determines the development of tourism; otherwise tourism development determines women empowerment. Interdependence between women and tourism in Lok Baintan is very high.

Women participations in tourism industry are higher in operative level than in managerial position due to low education and unskill [23], [24]. Training and capacity building, and financial support are needed to increase the empowerment of women and development of women capacity in tourism industry [20].

\section{CONCLUSION}

Women in Lok Baintan Floating Market have the important role. Women trade the local product such as handicraft, agriculture product, fishery product, culinary product. Women have the role as the trader in Lok Baintan Floating Market. Women also have the role for merchandise collecting. Women's activities in Lok Baintan have become a tourist attraction. Women work on informal sector, so that they get the low income; but women activity has an impact for family welfare, local economic, and tourism development in Lok Baintan Floating Market. 


\section{ACKNOWLEDGMENTS}

This research is funded by the Ministry of Research, Technology, and Higher Education through research grant. The author would like to thank for the research funding.

\section{REFERENCES}

[1] Normelani, E. 2016. The floating market of Lok Baitan, Kalimantan. Journal of Indonesian Tourism and Development Studies 4(1), 1-4.

[2] Normelani, E., M. S. Djati, T. Hidayat and L. Hakim. 2015. Tourist profiles and perception as a basic planning for sustainable tourism development Lok Baitan Floating Market, South Kalimantan. IOSR Journal of Environmental Science, Toxicology and Food Technology 9 (11 Ver. II), 11-16.

[3] Normelani, E. 2016. River, Culture and Tourism in Lok Baintan, South Kalimantan. Journal of Indonesian Tourism and Development Studies 4(2), 57-62.

[4] Rahmini, N., M. Pudjihardjo, A. Hoetoro and A. Manzilati. 2015. The role of bonding, bridging and linking at traditional markets in Indonesia: a study at Lok Baintan floating market Banjar Regency South Kalimantan. Journal of Applied Economic and Business 3(3), 76-88.

[5] Avornyo, R. 2013. Rural women's role in the socio-economic growth and well-being of Ghana: a case study of women operating within the informal sector. Journal of Global Initiatives 8(1 \& 2), 103-120.

[6] Kyaruzi, I. S. and M. R. Marković. 2009. Female entrepreneurship and local economic growth. Outskirts Press, Inc. Denver, Colorado.

[7] Ampumuza, C., F. van der Heijden, N. Hendriks, R. Klunder, J. Mazurek, F. van de Mosselaer, E. Ong, S. Pan and I. van Rumpt. 2008. Women empowerment for tourism. Project Wageningen University. Netherlands.

[8] Hakim, L. 2004. Dasar-dasar ekowisata. Bayumedia. Malang.

[9] UN Women. 2011. The global report on women in tourism 2010. World Tourism Organization (UNWTO) and the United Nations Entity for Gender Equality and the Employment of Women (UN Women), New York.

[10] Arisanty, D., E. Normelani, H. P. N. Putro and M. Z. A. Anis. 2017. Model pemberdayaan perempuan sebagai upaya pengembangan Community Based Tourism (CBT) berbasis ekonomi kreatif. Research Report. Lambung Mangkurat University. Banjarmasin.

[11] Fatchan, A. 2015. Metode penelitian kualitatif (pendekatan etnografi dan etnometodologi untuk penelitian ilmu-ilmu sosial). Ombak Publisher. Yogyakarta.

[12] Hakim, L. 2014. Etnobotani dan manajemen kebun-pekarangan rumah. Selaras Publisher. Malang.

[13] Sukenti, K., Hakim, L., Indriyani, S., Purwanto, Y., \& Matthews, P. J. (2016). Ethnobotanical study on local cuisine of the Sasak tribe in Lombok Island, Indonesia. Journal of Ethnic Foods 3(3), 189-200.

[14] Kladou, S., Bakas, F., Kladou, M. Cultural destinations and the role of gender in sustainable tourism development: Focusing on handicraft entrepreneurs. In: Critical Tourism Conference V, Sarajevo.

[15] Giuliano, P. 2014. The role of women in society: from preindustrial to modern times. CESifo Economic Studies Advance Access published. Los Angeles.

[16] Cukier J., J. Norris, G. Wall. 1996. The involvement of women in the tourism industry of Bali, Indonesia. The Journal of Development Studies, Volume 33, Issue 2, 248-270.

[17] International Labour Organization. 2010. Gender mainstreaming in local economic development strategies a guide. LED Programme, Bureau for Gender Equality. ILO. Geneva.

[18] Bradshaw, S., J. Castellino and B. Diop. 2013. Women's role in economic development: overcoming the constraints. Background paper for the high-level panel of eminent persons on the post. 2015 Development Agenda, the Sustainable Development Solutions Network Thematic Group on the Challenges of Social Inclusion: Gender, Inequalities and Human Rights.

[19] Cave, P., S. Kilic. 2010. The Role of Women in Tourism Employment With Special Reference to Antalya, Turkey. Journal of Hospitality Marketing \& Management Volume 19, Issue 3: Tourism Behavior and Marketing, 280-292.

[20] Mrema, A. A. 2014. Tourism and women empowerment in Monduli District, ArushaTanzania. African Journal of Hospitality, Tourism and Leisure 4(2), 1-14. 
[21] Sony, K. C. 2012. Roles and challenges of women in tourism sector of Western Nepal: a micro- ethnographic study. Neval Tourism and Development Review 2(1), 32-58.

[22] Joseph. 2014. Local Involvement in Tourism with Special Reference to Women at Bekal Fort Region in Kasaragod, Kerela, India. EPRA International Journal of Economic and Business Review 2(4), 41-46.

[23] Paudel, D.R., Malla, T.B., 2010. Women's Managerial Level Involvement in Tourism Sector in Pokhara. The Journal of Nepalese Business Studies VII (1), 39-52.

[24] Obadić, A., I. Marić. 2009. The Significance of Tourism as an Employment Generator of Female Labour Force. Ekon. Misao Praksa DBK. God XVIII.BR. 1, 93-114. 